\title{
Studi Kualitas Air Sungai Karang Mumus Ditinjau dari Parameter Escherichia coli Untuk Keperluan Higiene Sanitasi
}

\author{
Andi Daramusseng*, Syamsir \\ Program Studi Kesehatan Lingkungan Universitas Muhammadiyah Kalimantan Timur, Samarinda \\ *Corresponding author: andidaramusseng@umkt.ac.id/ 082344974329
}

Info Artikel : Diterima 16 November 2019 ; Disetujui 29 Mei 2020 ; Publikasi 1 April 2021

Cara Sitasi (Vancouver): Daramusseng A, Syamsir S. Studi Kualitas Air Sungai Karang Mumus Ditinjau dari Parameter Escherichia coli Untuk Keperluan Higiene Sanitasi. Jurnal Kesehatan Lingkungan Indonesia [Online]. 2021 Apr;20(1):1-6. https://doi.org/10.14710/jkli.20.1.1-6.

\begin{abstract}
ABSTRAK
Latar belakang : Degradasi kualitas perairan dapat terjadi akibat adanya zat pencemar yang mempengaruhi dan mengubah kondisi lingkungan perairan seperti Escherichia coli (E. coli). Tujuan dalam penelitian ini adalah untuk menganalisis kualitas air sungai Karang Mumus ditinjau dari parameter E. coli untuk Keperluan higiene sanitasi.

Metode: Metode dalam penelitian ini adalah observasi dan pemeriksaan laboratorium. Pengambilan sampel air dilakukan di sungai utama sebanyak tujuh titik. Penentuan titik pengambilan sampel air ini berdasarkan potensi sumber pencemar mulai dari hulu sampai ke hilir dengan kriteria terdapat daerah padat penduduk, peternakan, mall, hotel dan pasar. Teknik analisis yang digunakan yaitu dengan membandingkan hasil uji laboratorium dengan Peraturan Menteri Kesehatan Republik Indonesia Nomor 32 Tahun 2017 tentang Standar Baku Mutu Kesehatan Lingkungan dan Persyaratan Kesehatan Air untuk Keperluan Higiene Sanitasi, Kolam Renang, Solus Per Aqua, dan Pemandian Umum.

Hasil: Hasil pengukuran Bakteri E. coli Sungai Karang Mumus, Kota Samarinda menunjukan bahwa kandungan bakteri $E$. coli terendah $<30 \mathrm{CFU} / 100 \mathrm{~mL}$ dan yang tertinggi $2100 \mathrm{CFU} / 100 \mathrm{~mL}$

Simpulan: Semua hasil pengukuran bakteri E. coli di Sungai Karang Mumus sudah melebihi baku mutu yang ditetapkan yaitu $0 \mathrm{CFU} / 100 \mathrm{~mL}$ sampel. Langkah untuk meminimalkan kontaminan bakteri ke sungai perlu diambil sehingga penggunaan air Sungai Karang Mumus tidak membahayakan kesehatan masyarakat setempat.
\end{abstract}

Kata Kunci: Sungai; E. coli; Sanitasi

\section{ABSTRACT}

Title: Study on the Quality of the Karang Mumus River Water in terms of Escherichia coli Parameters For the Purpose of Hygiene Sanitation

Background: Water quality degradation can occur due to the presence of pollutants that affect and change the condition of the aquatic environment such as Escherechia coli (E. coli). The purpose of this study was to analysis of Karang Mumus River Water quality in terms of Escherichia coli parameters for the purpose of hygiene sanitation.

Method: The method in this research is observation and laboratory examination. Water sampling was taken in the main river for seven points. The determination of this water sampling point is based on potential sources of pollutants from upstream to downstream where there are densely populated areas, farms, malls, hotels, and markets. The analysis technique used is by comparing the results of laboratory tests with the Regulation of the Minister of Health of the Republic of Indonesia Number 32 the year 2017 concerning the Standards of Environmental Health Quality Standards and Water Health Requirements for Sanitary Hygiene, Swimming Pools, Solus Per Aqua, and Public Baths. 
Result: The measurement results of E. coli Bacteria in Karang Mumus River, Samarinda City showed that the lowest E. Coli bacteria content was $<30 \mathrm{CFU} / 100 \mathrm{~mL}$ and the highest was $2100 \mathrm{CFU} / 100 \mathrm{~mL}$.

Conclusion: All measurement results of E. coli bacteria in the Karang Mumus River have exceeded the established quality standard of $0 \mathrm{CFU} / 100 \mathrm{~mL}$ sample. Steps to minimize bacterial contaminants to the river need to be taken so that the use of Karang Mumus river water does not endanger the health of the local community.

Keywords: River; E.coli; Sanitation

\section{PENDAHULUAN}

Sungai Karang Mumus sebagai sumber kehidupan masyarakat di daerah aliran sungai telah mengalami penurunan kualitas. Hal ini ditandai dengan kondisi air yang berwarna hitam, adanya bau yang dihasilkan dari pembusukan sampah, dan banyaknya sampah yang tergenang di permukaan air. Umumnya daerah aliran sungai ini dimanfaatkan untuk daerah permukiman, tempat berbagai jenis usaha seperti pengolahan tahu dan tempe, hotel, pasar, peternakan, daerah pertanian dan sebagian lagi masih berupa lahan kosong. Jenis penggunaan lahan dapat berdampak besar pada tingkat pencemaran mikroba ke sungai. ${ }^{(1)}$ Permukiman di sepanjang aliran Sungai Karang Mumus adalah pemukiman padat penduduk yang sebagian besar warganya masih memanfaatkan air sungai untuk keperluan higiene sanitasi.

Peraturan Menteri Kesehatan Republik Indonesia Nomor 32 Tahun 2017 menyatakan bahwa air untuk Keperluan Higiene Sanitasi digunakan untuk pemeliharaan kebersihan perorangan seperti mandi dan sikat gigi, serta untuk keperluan cuci bahan pangan, peralatan makan, pakaian dan air baku air minum. ${ }^{(2)}$ Air yang digunakan untuk keperluan higiene sanitasi harus memenuhi syarat baik persyaratan secara fisik, kimia maupun biologi. Salah satu parameter kualitas biologi air adalah bakteri $E$. coli.

Bakteri E. coli adalah kelompok bakteri yang hidup di usus bagian bawah hewan berdarah panas, termasuk manusia. E. coli yang dikeluarkan dari tubuh akan menimbulkan bahaya pada tanah, sedimen dan air. ${ }^{(3)}$ Oleh karena itu, E. coli dalam perairan dapat mengindikasikan keberadaan patogen dari kotoran hewan atau manusia. ${ }^{(4)}$ Beberapa kemungkinan sumber kontaminasi tinja dalam perairan seperti limpasan pertanian, satwa liar yang menggunakan air sebagai habitat alami mereka, limpasan dari daerah yang terkontaminasi dengan kotoran hewan peliharaan, pabrik pengolahan air limbah, dan sistem septik di tempat. ${ }^{(5)}$ Penelitian yang dilakukan oleh Yuniarno (2005), menemukan kandungan E. coli di Sungai Bengawan Solo bagian hulu 2400/100 mL dan di daerah hilir $>18000$. Hal tersebut dikarenakan masih banyaknya masyarakat yang mempunyai kebiasaan buang air besar, buang limbah dan buang sampah di sungai. ${ }^{(6)}$ Kurangnya pemahaman masyarakat akan bahaya bakteri $E$. coli menyebabkan kurangnya kesadaran dan kemauan untuk melakukan pencegahan terhadap kontaminasi bakteri tersebut.

Penurunan kualitas biologi pada perairan sungai akan mengakibatkan timbulnya masalah kesehatan manusia khususnya yang disebabkan oleh E. coli seperti diare, infeksi saluran kemih, penyakit pernapasan, pneumonia, dan penyakit lainnya. ${ }^{(7)}$ Selain itu, menurut Ingerson dan Reid (2011), infeksi dapat menyebar dalam tubuh (ke darah, hati, dan sistem saraf). ${ }^{(8)}$ Keberadaan E. coli sebagai indikator kualitas perairan menjadi salah satu alasan pentingnya menjaga air sungai dari pencemaran yang dapat menjadi sumber berbagai penyakit. Untuk itu, perlu adanya pemeriksaan kandungan bakteri $E$. coli pada air Sungai Karang Mumus. Tujuan dari penelitian ini yaitu untuk menganalisis kualitas air sungai Karang Mumus ditinjau dari parameter bakteri E. coli untuk keperluan higiene sanitasi.

\section{MATERI DAN METODE}

Penelitian ini merupakan penelitian yang dilakukan di Sungai Karang Mumus yang merupakan anak Sungai Mahakam. Pengambilan sampel air dilakukan di sungai utama sebanyak tujuh titik. Penentuan titik pengambilan sampel ini berdasarkan potensi sumber pencemar mulai dari hulu sampai ke hilir. Kriteria daerah pengambilan sampel adalah daerah padat penduduk, peternakan, mall, hotel dan pasar. Pengambilan sampel dilaksanakan pada bulan Juli - Agustus 2019. Proses pengambilan sampel dilaksanakan pada pagi hari dari jam 08.00 WITA sampai jam 12.00 WITA. Hal ini dapat mengidentifikasi adanya kenaikan pemakaian air bersih untuk kegiatan domestik yang nantinya akan menjadi air limbah dan masuk ke dalam Sungai dan mempengaruhi kualitas air sungai.

Pemeriksaan sampel dilakukan di Balai Riset dan Standardisasi Industri Kota Samarinda, Kalimantan Timur. Teknik analisis yang digunakan yaitu dengan membandingkan hasil uji laboratorium dengan Peraturan Menteri Kesehatan Republik Indonesia Nomor 32 Tahun 2017 tentang Standar Baku Mutu Kesehatan Lingkungan dan Persyaratan Kesehatan Air untuk Keperluan Higiene Sanitasi, Kolam Renang, Solus Per Aqua, dan Pemandian Umum.

\section{HASIL DAN PEMBAHASAN}

Penelitian ini dilakukan di wilayah Sungai Karang Mumus Kota Samarinda. Sungai Karang Mumus merupakan anak Sungai Mahakam yang 
membelah Kota Samarinda dengan daerah aliran sungai (DAS) seluas 32.196,3 ha. Lokasi penelitian dapat dilihat pada gambar 1 dibawah ini.

Kualitas air Sungai Karang Mumus berdasarkan parameter E. coli dapat dilihat pada tabel 1, Hasil pengukuran Bakteri E. coli yang dilakukan di Sungai Karang Mumus Kota Samarinda menunjukan bahwa kandungan bakteri $E$. coli terendah $<30 \mathrm{CFU} / 100 \mathrm{~mL}$ dan yang tertinggi $2100 \mathrm{CFU} / 100 \mathrm{~mL}$. Berdasarkan PERMENKES RI No. 32 Tahun 2017 tentang standar baku mutu kesehatan lingkungan dan persyaratan kesehatan air untuk keperluan higiene sanitasi, semua hasil pengukuran sudah tidak memenuhi syarat parameter E. coli $(0 \mathrm{CFU} / 100 \mathrm{~mL})$.

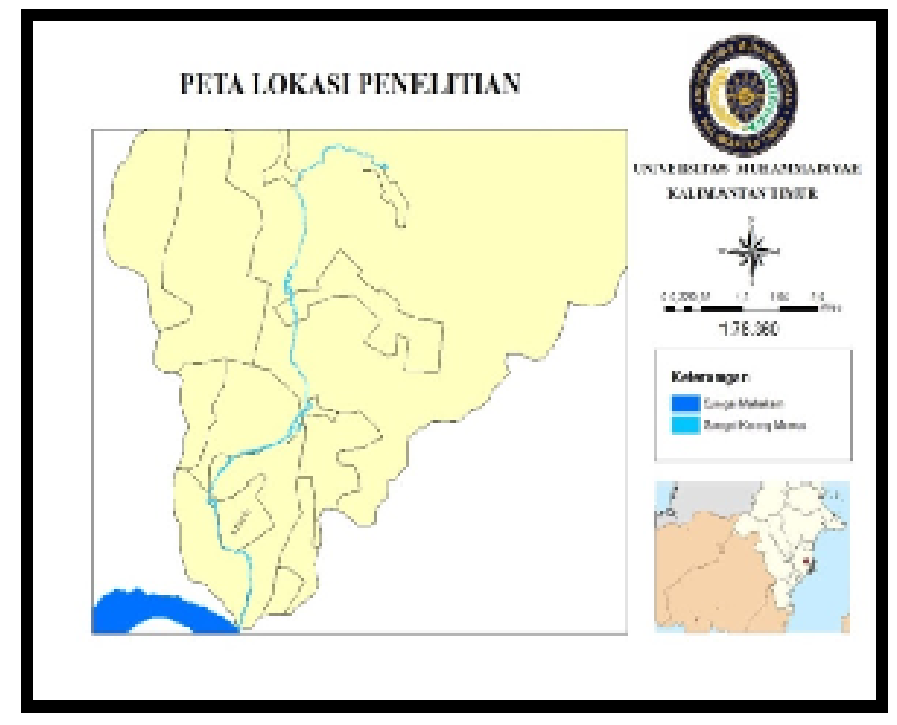

Gambar 1. Lokasi Penelitian

Tabel 1. Hasil Pengukuran Parameter Bakteri Escherichia coli pada Air Sungai Karang Mumus, Kota Samarinda

\begin{tabular}{lccc}
\hline \multicolumn{1}{c}{ Lokasi } & $\begin{array}{c}\text { Hasil Pengukuran } \\
\text { (CFU/100 mL }\end{array}$ & $\begin{array}{c}\text { Nilai Ambang Batas } \\
\text { (Permenkes 2017) }\end{array}$ & Potensi Pencemar \\
\hline Jembatan PM.Noor & $<30$ & & Permukiman dan pasar \\
Gang Nibung & 90 & & Permukiman dan pasar \\
Jembatan Perniagaan & $<30$ & & $\begin{array}{c}\text { Permukiman dan pasar } \\
\text { Permukiman, hotel }\end{array}$ \\
Jembatan Agus Salim & 430 & $0 \mathrm{CFU} / 100 \mathrm{~mL}$ & $\begin{array}{c}\text { Permukiman, pasar tradisional dan } \\
\text { pasar unggas }\end{array}$ \\
Jembatan Lambung mangkurat & 2100 & & $\begin{array}{c}\text { Permukiman, pasar tradisional dan } \\
\text { pasar unggas }\end{array}$ \\
Jembatan Kehewanan & 430 & & Permukiman dan pasar tradosional \\
Jembatan Sungai Dama & 930 &
\end{tabular}

Sumber: Data Primer

Tabel 2.Distribusi Kepemilikan Jamban dan Pemanfaatan Air Sungai Karang Mumus, Kota Samarinda

\begin{tabular}{cccccccc}
\hline \multirow{2}{*}{ No Variabel } & \multicolumn{2}{c}{ Ya } & \multicolumn{2}{c}{ Tidak } & \multicolumn{2}{c}{ Total } \\
\cline { 3 - 8 } & & $\mathrm{n}$ & $\%$ & $\mathrm{n}$ & $\%$ & $\mathrm{n}$ & $\%$ \\
\hline \multirow{2}{*}{1} & Kepemilikan Jamban & & & & & & \\
& Memiliki Jamban & 125 & 83,3 & 25 & 16,7 & 150 & 100 \\
& Jamban di Atas Sungai & 75 & 60 & 50 & 40 & 125 & 100 \\
& Jamban Memiliki Septick Tank & 49 & 32,7 & 76 & 60,8 & 125 & 100 \\
2 & Pemanfaatan Air Sungai Karang Mumus & & & & & & \\
& Mandi & 131 & 87,3 & 19 & 12,7 & 150 & 100 \\
& Mencuci pakaian & 92 & 61,3 & 58 & 38,7 & 150 & 100 \\
& Mencuci peralatan dapur & 80 & 53,3 & 70 & 46,7 & 150 & 100 \\
\hline
\end{tabular}

\section{Sumber: Data Primer}

Berdasarkan tabel 2 di atas menunjukkan distribusi kepemilikan jamban dari 150 responden terdapat $125(83,3 \%)$ yang memiliki jamban. Dari 125 responden yang memiliki jamban terdapat $75(60 \%)$ jamban yang berada di atas sungai dan 76 (60,8\%) yang tidak memiliki septick tank. Adapun distribusi pemanfaatan air Sungai Karang Mumus, paling banyak digunakan untuk keperluan mandi sebanyak 
$131(87,3 \%)$, peruntukan untuk mencuci pakaian sebanyak $92(61,3 \%)$, dan mencuci peralatan dapur sebanyak $80(53,5 \%)$.

\section{Kandungan E. coli Sungai Karang Mumus}

Air merupakan media yang baik untuk kehidupan bakteri patogen seperti bakteri E. coli. E. coli memberikan bukti konkret mengenai adanya pencemaran feses dalam air. ${ }^{(9)}$ Pengujian pada sampel air Sungai Karang Mumus diperoleh hasil kandungan $E$. Coli terendah $<30 \mathrm{CFU} / 100 \mathrm{~mL}$ dan yang tertinggi $2100 \mathrm{CFU} / 100 \mathrm{~mL}$. Berdasarkan PERMENKES RI No. 32 Tahun 2017 tentang standar baku mutu kesehatan lingkungan dan persyaratan kesehatan air untuk keperluan higiene sanitasi, semua hasil pengukuran sudah tidak memenuhi syarat parameter E. coli $(0 \mathrm{CFU} / 100 \mathrm{~mL})$. $E$ coli memiliki hubungan yang kuat dengan lahan terbangun, seperti permukiman dan kawasan komersil. ${ }^{(10)}$

Keberadaan permukiman dan berbagai aktivitas disekitar Sungai Karang Mumus seperti pasar tradisional dan hotel menyebabkan tingginya kandungan E. coli. Limbah domestik dari berbagai aktivitas masyarakat tersebut masuk ke badan sungai dan mencemari sungai. Limbah domestik merupakan sumber polutan dalam pencemaran air. ${ }^{(11)}$ Penelitian yang dilakukan oleh Khotimah (2013), menyatakan bahwa pengaruh buangan organik seperti limbah domestik dari aktivitas manusia merupakan faktor penyebab tingginya kandungan Colirofm di sungai. ${ }^{(12)}$ Penelitian lain yang dilakukan oleh Pemerintah Kota Surabaya dan Dinas Lingkungan Hidup (2018), menyatakan bahwa permukiman padat penduduk dan industri skala rumah tangga atau usaha kegiatan lain yang limbahnya dibuang ke sungai menyebabkan tingginya tingkat pencemaran sungai. ${ }^{(13)} \mathrm{Hal}$ tersebut juga diperkuat oleh Rizki Adrianto (2018), menyatakan bahwa permukiman padat penduduk dimana jarak pembuangan limbah rumah tangga dengan sumber air cenderung berdekatan menyebabkan terjadinya pencemaran bakteri coliform. ${ }^{(14)}$

Keberadaan jamban di atas Sungai Karang Mumus dengan kondisi yang tidak memenuhi persyaratan jamban sehat juga menjadi faktor penyebab tingginya kandungan E.coli di Sungai Karang Mumus. Hasil wawancara dan survei yang dilakukan terhadap 150 responden diperoleh rumah yang memiliki jamban sebanyak $125 \quad(83,3 \%)$. Dari125 rumah yang memiliki jamban terdapat $60 \%$ jamban yang berada di atas sungai dan $60,8 \%$ yang tidak memiliki septick tank. Jamban yang tidak memiliki septic tank menyebabkan kotoran/tinja langsung masuk ke dalam badan air. Meskipun terdapat juga jamban yang memiliki septic tank tapi jarak septic tank sangat dekat dengan sungai sehingga dikhawatirkan akan mengalami kebocoran dan mencemari sungai.

Keberdaan Septic tank dan persyaratan jarak dengan sumber air sangat penting diperhatikan agar jamban tidak menimbulkan pencemaran. Penelitian Meisura Marlinda dkk. (2019), menyatakan bahwa sumber kontaminasi bakteri pada tanah dan air tanah dikarenakan tidak adanya septic tank dan jarak yang dekat antara septic tank dengan sumber air. ${ }^{(15)}$ Selain itu, Rajesh Nithyanandam dkk. (2015), juga menyatakan bahwa tangki septik yang rusak menyebabkan tingginya $E$. coli pada air sungai. ${ }^{(16)}$ Jamban sehat harus memiliki bangunan yang kuat sehingga dapat memberikan keamanan dan privasi serta memiliki septic tank sehingga tidak menjadi sumber pencemaran lingkungan. ${ }^{(17)}$

Kegiatan yang terdapat di kawasan Sungai Karang Mumus selain permukiman, pasar tradisional dan hotel adalah pasar hewan (unggas). Bakteri E. coli dapat ditemukan pada sapi, domba, babi, rusa, anjing dan unggas. ${ }^{(18)}$ Kegiatan usaha ternak seperti peternakan babi yang ada disisi sungai dapat mengakibatkan konsentrasi Total coliform dalam air ${ }^{(19),(20)} \mathrm{Hal}$ ini sejalan dengan penelitian Puspita dkk. (2016), menyatakan bahwa kotoran ayam yang mengalir ke sungai akan mempengaruhi kualitas air Sungai. ${ }^{(21)}$

\section{Pemanfaatan Air Sungai Karang Mumus}

Air sungai Karang Mumus merupakan sumber kehidupan bagi masyarakat setempat dan sekitarnya. Sebagian masyarakat yang tinggal disekitar bantaran sungai masih menggunakan untuk air Sungai Karang Mumus untuk keperluan higiene sanitasi mulai dari mandi, mencuci pakaian sampai mencuci peralatan dapur. Wawancara yang dilakukan pada 150 responden diperoleh hasil bahwa pemanfaatan air Sungai Karang Mumus paling banyak digunakan untuk keperluan mandi sebanyak $131 \quad(87,3 \%)$, peruntukan untuk mencuci pakaian sebanyak 92 $(61,3 \%)$, dan mencuci peralatan dapur sebanyak 80 $(53,5 \%)$.

Masyarakat yang tinggal di wilayah Sungai Karang Mumus kebanyakan masyarakat menengah ke bawah yang mempunyai keterbatasan untuk membeli air PDAM sehingga tidak mempunyai pilihan untuk tidak menggunakan air Sungai Karang Mumus. Padahal kondisi air Sungai Karang Mumus saat ini telah mengalami penurunan kualitas baik secara fisik, kimia maupun biologi. Secara fisik air sungai karang mumus berwarna hitam dan bau akibat sampah yang dibuang oleh masyarakat. Sedang secara kimia berdasarkan hasil penelitian Pramaningsih (2017), menunjukan konsentrasi BOD, COD dan TSS di Sungai Karang Mumus cukup tinggi khususnya di daerah yang padat permukiman. ${ }^{(2)}$ Adapun kualitas biologi air Sungai Karang Mumus juga sudah buruk dibuktikan dari hasil pemeriksaan E. coli yang mencapai $2100 \mathrm{CFU} / 100 \mathrm{~mL}$.

Kebiasaan menggunakan air sungai untuk kebutuhan sehari-hari, selain karena keterbatasan kemampuan daya beli air PDAM juga dipengaruhi oleh budaya sebagaimana penelitian Yunida (2018) 
yang menemukan adanya hubungan yang bermakna antara budaya terhadap perilaku penggunaan air sungai $^{(23)}$ Budaya merupakan suatu tatanan meliputi pengetahuan, keyakinan, seni, moral, adat-istiadat serta kemampuan dan kebiasaan lain yang dimiliki manusia sebagai bagian masyarakat. ${ }^{(24)}$ Kebiasaan yang dilakukan sejak kecil maka akan berpengaruh ketika seseorang dewasa. Misalnya, seseorang yang sejak kecil sudah terbiasa menggunakan air sungai maka akan sulit diubah setelah dewasa. Kondisi serupa mengenai memanfaatan air sungai untuk keperluan sanitasi juga terjadi pada masyarakat disekitar Sungai Kuin Banjarmasin seperti pemanfaatan untuk keperluan mandi,mencuci,sanitasi dan bahkan digunakan untuk masak dan minum. ${ }^{(25)}$

Pemanfaatan air yang tidak memenuhi persyaratan untuk keperluan higiene sanitasi akan menimbulkan water borne disease yaitu penyakit yang disebabkan oleh konsumsi air terkontaminasi oleh kotoran atau urin manusia dan hewan yang mengandung patogen. ${ }^{(26)}$ Penularan patogen ini terjadi saat menggunakan air yang terkontaminasi untuk minum, persiapan makanan, dan mencuci pakaian. ${ }^{(27)}$ Penyakit tersebut paling rentan terjadi pada masyarakat yang menggunakan air tanpa melalui proses pengolahan terlebih dahulu. Menurut Murphy (2014), air tanah dan air permukaan paling berisiko tercemar bakteri patogen yang dapat menyebabkan Acute Gastrointestinal Illness. ${ }^{(28)}$

Jenis air untuk keperluan higiene sanitasi adalah air yang digunakan untuk keperluan seharihari dan untuk pemeliharaan kebersihan perorangan seperti mandi, gosok gigi, serta untuk keperluan bahan pangan, peralatan makan dan pakaian yang kualitasnya berbeda dengan kualitas air minum ${ }^{(1)}$. Agar air yang digunakan tidak memberi dampak negatif bagi lingkungan dan kesehatan manusia maka parameter kualitas air bersih harus dipenuhi.

\section{SIMPULAN}

Kandungan E. coli pada tujuh titik sampel di Sungai Karang Mumus Kota Samarinda terendah $<30$ CFU/100 mL dan tertinggi $2100 \mathrm{CFU} / 100 \mathrm{~mL}$. Semua hasil pengukuran sudah tidak memenuhi syarat parameter E. coli (0 CFU/100 mL) dan tidak layak digunakan untuk keperluan higiene sanitasi. Langkah untuk meminimalkan kontaminan bakteri ke sungai perlu diambil sehingga penggunaan air sungai Karang Mumus tidak membahayakan kesehatan masyarakat setempat.

\section{DAFTAR PUSTAKA}

1. Ouattara NK, Passerat J, Servais P. Faecal contamination of water and sediment in the rivers of the Scheldt drainage network. Environ Monit Assess J. 2011;183(1-4):243-57.

2. Moeloek NF. PERMENKES RI No. 32 Tahun 2017 tentang Standar Baku Mutu Kesehatan Lingkungan Dan Persyaratan Kesehatan Air Untuk Keperluan Higiene Sanitasi, Kolam
Renang, Solus Per Aqua, dan Pemandian Umum. 2017;

3. Howard C. Berg. E. coli in Motion. New York: AIP Press; 2004. 2 p.

4. Series NZE reporting. River water quality bacteria (Escherichia coli). New Zealand: Environmental Indicators; 2015.

5. Lewis L, Writer G. The Water Project: Health Implications of Escherichia coli (E. Coli) in Recreational and Drinking Water. 2019.

6. Yuniarno S, Sulistiyani, Raharjo M. Hubungan Kualitas Air Sumur dengan Kejadian Diare di Daerah Aliran Sungai ( DAS ) Bengawan Solo. J Kesehat Lingkung Indones [Internet]. 2005;4(2):65-70. Available from: https://ejournal.undip.ac.id/index.php/jkli/article/ view/9632

7. Centers for Disease Control and Prevention. E. coli (Escherichia coli). 2014.

8. Michael, Ingerson-Mahar, Reid A. E. coli: Good, bad, \& deadly. 2015;(November 2011).

9. World Health Organization (WHO). WHO guidelines for drinking-water quality. In: $3 \mathrm{rd}$ ed. 2006.

10. Genisa MU, Auliandari L. Sebaran Spasial Bakteri Koliform di Sungai Musi Bagian Hilir. Maj Ilm Biol Biosf A Sci J [Internet]. 2018;35(3):131-8. Available from: https://www.researchgate.net/profile/Lia_Auliand ari/publication/330553710_Sebaran_Spasial_Bakt eri_Koliform_di_Sungai_Musi_Bagian_Hilir/link

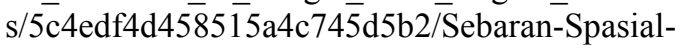
Bakteri-Koliform-di-Sungai-Musi-BagianHilir.pdf

11. Widyastuti M, Haryono E. Water quality characteristics of Jonge Telaga (Doline Pond) as water resources for the people of Semanu District Gunungkidul Regency. Indones J Geogr [Internet]. 2016;48(2):157-67. Available from: https://pdfs.semanticscholar.org/0694/afdbb615c1 046c4d2874a4f66f6734114813.pdf

12. Khotimah S. Kepadatan Bakteri Coliform di Sungai Kapuas Kota Pontianak. Pros SEMIRATA. 2013;1(1):339-49.

13. Surabaya PK, Hidup DL. Kajian Penanggulangan Beban Pencemaran Sungai Kali Tebu dengan Parameter Escherichia coli. 2018.

14. Adrianto R. Pemantauan Jumlah Bakteri Coliform Di Perairan Sungai Provinsi Lampung. J Maj Teknol Agro Ind [Internet]. 2018;10(1):1-6. Available from: http://ejournal.kemenperin.go.id/tegi/article/view 13920

15. Marlinda M, Moelyaningrum AD, Ellyke. Keberadaan Bakteri Eschericia Coli dan Coliform Pada Sumur Gali dan Bor Rumah Pemotongan Hewan (RPH). J Kesehat Lingkung [Internet]. 2019;6(1):5-10.

16. Nithyanandam R, Huan TW, Thao Thy NH. Case study: Analysis of water quality in Sungai Batu 
Ferringhi. J Eng Sci Technol [Internet]. 2015;10(Special Issue 2 on23December2014):15-25. Available from: https://www.researchgate.net/publication/282559 047_Case_study_Analysis_of_water_quality_in_ Sungai_Batu_Ferringhi

17. World $\overline{\text { Health }}$ Organization (WHO). Guidelines on sanitation and health [Internet]. World Health Organization. 2018. 1-220 p. Available from: http://www.who.int/water_sanitation_health/publi cations/guidelines-on-sanitation-and-health/en/

18. Pfizer Animal Health. A Guide to E. coli O157 in Cattle [Internet]. 2011. Available from: https://www.zoetisus.com/_locale-assets/mcmportal-

assets/services/documents/srpecoli/e_coli_tech_m anual_final.pdf

19. Rompas TM, Rotinsulu WC, Polii JVB. Analysis of E-Coli Content and Total Coliform of Raw Water. E-Journal Univ Sam Ratulangi [Internet]. 2019; Available from: https://ejournal.unsrat.ac.id/index.php/cocos/articl e/view/25742

20. Yogafanny E. Pengaruh Aktifitas Warga di Sempadan Sungai terhadap Kualitas Air Sungai Winongo. J Sains \&Teknologi Lingkung [Internet]. 2015;7(1):29-40. Available from: https://journal.uii.ac.id/JSTL/article/view/3494/30 87

21. Puspita I, Ibrahim L, Hartono D. Penurunan Kualitas Air Sungai Karang Anyar Kota Tarakan ( Influence of The Behavior of Citizens Residing in Riverbanks to The Decrease of Water Quality in The River of Karang Anyar Tarakan City ). J Mns dan Lingkung [Internet]. 2016;23(2):249-58. Available from: https://jurnal.ugm.ac.id/JML/article/view/18797
22. Pramaningsih V, Suprayogi S. Kajian Persebaran Spasial Kualitas Air Sungai Karang Mumus , Samarinda , Kalimantan Timur. J Pengelolaan Sumberd Alam dan Lingkung [Internet]. 2017;7(3):211-8. Available from: https://journal.ipb.ac.id/index.php/jpsl/article/vie $\mathrm{w} / 15156$

23. Yunida SH. Hubungan Pengetahuan, Sikap, dan Budaya dengan Perilaku Penggunaan Air Sungai (Studi Di Wilayah Kerja Puskesmas Martapura 2). Indones J Public Heal [Internet]. 2018;13(2). Available from: https:/ejournal.unair.ac.id/IJPH/article/view/8244

24. Peter Hwkins. Creating a Coaching Habit. New York: Bell and Bain Ltd; 2012.

25. Santy DA, Adyatma S, Huda N. Analisis Kandungan Bakteri Fecal Coliform pada Sungai Kuin Kota Banjarmasin. J Maj Geogr Indones. 2017;31(2):51.

26. Pillay MS, Selim MI, Siru D. Unicef Handbook On Water Quality. Vol. 13, United Nations Children's Fund (UNICEF). New York; 2008. 8$10 \mathrm{p}$.

27. HH Patel. Water-Borne Diseases [Internet]. News Medical Life Science. 2019. Available from: https://www.news-medical.net/health/WaterBorne-Diseases.aspx

28. Murphy HM, Pintar KDM, McBean EA, Thomas MK. A systematic review of waterborne disease burden methodologies from developed countries. J Water Health [Internet]. 2014;12(4):634-55. Available from: https://www.researchgate.net/publication/263144 452_A_systematic_review_of_waterborne_diseas e_burden_methodologies_from_developed_count ries 